\title{
PELATIHAN PEMBUATAN PERMEN DAN JELLY ANTANAN SEBAGAI SUPLEMEN UNTUK MENINGKATKAN KEMAMPUAN DAYA INGAT BAGI SANTRI PENGHAFAL AL-QURAN DI PESANTREN SABILA CITEUREUP BOGOR
}

\author{
Tarma $^{1)}$, Nurlaila A $\mathbf{M}^{2}$, Mulyati $^{3}$ \\ Jurusan IKK Fakultas Teknik Universitas Negeri Jakarta
}

\begin{abstract}
ABSTRAK
Pondok Pesantren Sabila yang berlokasi di Citeureup Kabupaten Bogor merupakan pondok pesantren untuk penghafal Al Qur'an. Menghafal merupakan salah satu aktivitas mental yang sangat memerlukan kondisi kesehatan yang baik. Menghafal Al Qur'an memiliki keutamaan dalam ajaran Islam. Untuk meningkatkan kemampuan hafalan, diperlukan asupan makanan yang dapat meningkatkan daya ingat, di antaranya ialah antanan. Atas dasar itu dilaksanakan kegiatan pengabdian masyarakat dengan judul "Pelatihan Pembuatan Permen dan Jelly Antanan Sebagai Suplemen untuk Meningkatkan Kemampuan Daya Ingat Bagi Santri Penghafal Al Qur'an di Pesantren Sabila Citeureup Bogor”. Kegiatan dari mulai persiapan, pelaskanaan dan evaluasi dilaksanakan selama tiga bulan terhitung mulai Juli s.d September 2015. Kegiatan dilaksanakan pada hari Jum'at, tanggal 11 September 2015 bertempat di aula Pondok Pesantren Sabilia Citeurup Bogor, diikuti oleh 20 orang santri. Materi pelatihan mencakup pengenalan tanaman antanan, teori dan praktik membuat permen jelly antanan serta proses pengemasan permen jelly antanan. Hasil pelatihan diketahui bahwa peserta pelatiha menguasai materi pelatihan yang telah disampaikan.
\end{abstract}

Kata Kunci : permen jelly antanan, daya ingat, penghafal Al Qur'an

\section{PENDAHULUAN}

Bagi umat Islam, penghafal Al Qur'an memiliki keistimewaan. Rasulullah SAW bersabda: “Penghafal Al Qur'an akan datang pada hari kiamat, kemudian Al Qur'an akan berkata, 'wahai Tuhanku pakaikanlah pakaian untuknya,' Kemudian orang itu dipakaikan mahkota karomah (kehormatan) Al Qur'an kembali meminta, 'Wahai Tuhanku tabahkanlah,' Lalu orang itu dipakaikan jubah karomah. Kemudian Al Qur'an memohon lagi, 'Wahai Tuhanku, ridailah dia,' Allah SWT pun meridhainya. Dan diperintahkan kepada orang itu, 'Bacalah dan teruslah naiki (derajatderajat surga). Allah SWT menambahkan bdari setiap ayat yang dibacanya tambahan nikmat 
dan kebaikan" (H.R. Baihaqi). Hadits lainnya menyebutkan bahwa: "Orang yang tidak mempunyai hafalan Al Qur'an sedikitpun adalah seperti rumah kumuh dan mau runtuh". Berdasarkan dua hadist tersebut diketahui betapa mulianya para penghafal Al Qur'an.

Pesantren Sabila yang berlokasi di Perum Griya Anggraini Blok C8 No. 15 Citeureup Kabupaten Bogor merupakan salah satu wahana bagi para penghafal $\mathrm{Al}$ Qur'an. Pesantren ini merupakan pesantren tahfidz, yaitu jenis pesantren yang menekankan pada penguasaan hafalan Al Qur'an oleh para santrinya. Di pesantren tersebut, para penghafal Al Qur'an adalah anak dan remaja yang seluruhnya anak yatim.

Kegiatan menghafal Al Qur'an tidaklah mudah. Memerlukan upaya yang serius dan rutin. Diperlukan kerja keras dari santri dalam menghafal ayat demi ayat AL Qur'an. Hafalan pun harus dicek kebenaran dan ketepatan bacaannya melalui kegiatan tasmi Qur'an. Setiap hari dituntut untuk melakukan muroja'ah sebagai bentuk laporan kemajuan hafalan Al Qur'an yang telah dikuasainya.

Menghafal quran membutuhkan kemampuan otak santri yang prima. Untuk mendapatkan kemampuan otak santri yang prima, diperlukan daya dukung yang ada di pesantren. Santri penghafal Al Qur'an perlu dijaga konsentrasinya, dikondisikan untuk selalu tenang dan khusyu, serta diperlukan asupan gizi yang baik.

Pesantren Sabila merupakan pesantren yang belum lama berdiri. Masih terdapat kekurangan atau masalah yang harus dicari solusinya. Di antara permasalahan yang ada yaitu belum adanya asrama yang representatif, belum memiliki tenaga penyiapan makanan yang profesional untuk memastikan asupan gizi para santri, dan sebagainya.

Untuk mengatasi belum optimalnya asupan gizi bagi para santri pengahfal $\mathrm{Al}$ Qur'an, perlu diupayakan suplemen makanan yang baik untuk perkembangan otak santri.
Banyak sekali jenis bahan makanan yang baik untuk meningkatkan daya ingat. Namun umumnya jenis bahan makanan atau makanan olahan untuk meningkatkan daya ingat harganya relatif mahal. Untuk itu, diperlukan upaya untuk membuat suplemen makanan untuk meningkatkan daya ingat tetapi dengan bahan baku yang mudah didapatkan serta harganya relatif murah. Di antara jenis bahan makanan yang baik untuk meningkatkan daya ingat adalah pegagan atau antanan yang dalam bahasa ilmiahnya dikenal dengan istilah Centella Asiatica.

Pegagan merupakan tanaman liar yang biasa hidup di tanah pekarangan. Tanaman pegagan ini tingginya bisa mencapai 7-10 cm. Daun tanaman pegagan berbentuk bulat, batangnya bersifat lunak dan beruas, serta tumbuh menjalar hingga panjangnya bisa mencapai satu meter. Tanaman pegagan memiliki banyak kandungan yang bermanfaat bagi kesehatan di antaranya triterpenoids, asiaticoside, thankuniside, isothankuniside, madecassoside, brahmoside, brahmic acid, brahminoside, madasiatic acid, meso-inositol, centelloside, carotenoids, hydrocotylin, vellarine, dan beberapa macam vitamin yaitu $\mathrm{A}, \mathrm{B}, \mathrm{E}, \mathrm{C}, \mathrm{K}$, serta mengandung nilai nutrisi yang membantu vitalitas tubuh dan berfungsi sedatif. Dari kandungan-kandungan yang dimiliki tersebut, pegagan dapat bermanfaat untuk menyembuhkan penyakit TBC, reumatik, demam, susah kencing, wasir bisul, darah tinggi, liver, gangguan metabolik; mengurangi kepikunan bagi orang tua atau menambah memori otak

Sudah banyak olahan antanan yang dijual di pasaran dalam bentuk teh maupun kapsul ekstrak antanan. Namun rasanya tidak terlalu enak dikonsumsi dalam teh kapsul. Terlebih lagi bagi santri penghafal Al Qur'an di Pesantren Sabila yang seluruhnya adalah usia SMP yang menyukai jenis makanan yang rasanya enak. Untuk itu, diperlukan pembuatan jenis makanan terbuat dari antanan yang enak dan disukai oleh anak usia SMP. Salah satu 
jenis makanan yang disukai oleh anak usia SMP adalah makanan yang berbentuk jelly atau atau permen. Dalam pengabdian ini yang akan dibuat adalah jelly dan permen antanan.

Selain diperlukan pembuatan produk, santri juga perlu diberikan keterampilan bagaimana membuat sendiri jelly dan permen antanan. Sehingga nantinya para santri dapat secara mandiri membuat jelly dan permen antanan juga untuk dikonsumni oleh mereka sendiri. Atas dasar itu, dipandang perlu untuk melakukan pelatihan pembuatan jelly dan permen antanan sebagai wujud kegiatan pengabdian masyarakat.

Berdasarkan pada analisis situasi di atas, permasalahan yang terjadi di Pondok Pesantren Sabila yang dirumuskan yaitu belum adanya suplemen untuk meningkatkan kemampuan daya ingat para santri dalam menghafal $\mathrm{Al}$ Qur'an. Kemudian pertanyaan yang diajukan sebagai basis pengabdian masyarakat ini ialah: "Bagaimana dampak pelatihan pembuatan permen jelly antanan terhadap kemampuang mengingat hafalan Al Qur'an pada santri di Pondok Pesantren Sabila Citeureup Kabupaten Bogor".

Sasaran dari kegiatan Pelatihan Pembuatan Jelly dan Permen Antanan ini adalah 20 orang santri dan pengelola (khususnya bagian konsumsi) di Pesantren Sabila Citeureup Kabupaten Bogor. Adapun target yang hendak dicapai yaitu Santri dan pegelola Pesantren Sabila memiliki:

1) pengetahuan yang memadai tentang kandungan yang terdapat dalam tanaman antanan;

2) pengetahuan yang memadai tentang manfaat tanaman antanan untuk meningkatkan daya ingat;

3) keterampilan membuat permen jelly antanan, dimulai dari pemilihan dan penyiapan bahan, proses pembuatan dan penyajian; dan

4) keterampilan membuat kemasan untuk produk jelly dan permen antanan.
Setelah pelaksanaan Pelatihan Pembuatan Jelly dan Permen Antanan ini, luaran yang diharapkan yaitu:

1) produk permen dan jelly antanan yang siap saji dalam bentuk kemasan yang dapat disimpan dalam waktu maksimal dua minggu; dan

2) keterampilan santri dan pengelola dalam membuat permen dan jelly antanan.

\section{METODE KEGIATAN}

Kegiatan pengabdian masyarakat ini dilaksanakan dengan tujuan:

1) meningkatkan pengetahuan kepada santri dan pengelola Pondok Pesantren Sabila tentang kandungan tanaman pegagan;

2) meningkatkan pengetahuan kepada santri dan pengelola Pondok Pesantren Sabila tentang manfaat tanaman pegagan bagi kesehatan;

3) meningkatkan keterampilan dalam membuat permen jelly antanan bagi santri dan pengelola Pondok Pesantren Sabila; dan

4) memberikan alternatif asupan makanan yang baik untuk meningkatkan daya ingat santri di Pondok Pesantren Sabila.

Ada manfaat yang diharapkan diperoleh melalui kegiatan ini. Di antara manfaat yang dapat diperoleh yaitu:

1) meningkatnya pengetahuan santri dan pengelola tentang kandungan dan manfaat antanan sebagai penunjang kemampuan menghafal Al Qur'an;

2) meningkatnya keterampilan santri dan pengelola dalam membuat permen jelly antanan yang dapat digunakan sebagai suplemen makanan sebagai penunjang kemampuan menghafal Al Qur'an; dan

3) berpeluang dijadikan sebagai usaha sampingan dari Pondok Pesantren Sabila yang berpotensi mendapatkan keuntungan finansial. 
Khalayak sasaran yang strategis dalam kegiatan Pelatihan Pembuatan Permen Jelly Antanan ini ialah seluruh santri di Pondok Pesantre Sabila Citeureup Kabupaten Bogor yang berjumlah 20 orang dengan rentangan usia 12-15 tahun. Selain santri, sasaran pelatihan ini juga termasuk pengelola dengan jumlah yang dilibatkan sebanyak 5 orang. Pondok Pesantren terletak di Perum Griya Anggraini Blok C8 No. 15 Citeureup Kabupaten Bogor.

Untuk memecahkan masalah belum adanya suplemen makanan, maka metode pendekatan yang dipilih adalah dalam bentuk pelatihan. Metode ini dipilih santri memiliki keterampilan yang bisa diandalkan dan dapat membuat sendiri jelly dan permen antanan. Tahapan dan prosedur kerja yang akan dilaksanakan sebagai berikut.

Pertama, penyusunan konsep pelatihan untuk mengidentifikasi:

1) standar kompetensi, kompetensi dasar dan indikator hasil pelatihan;

2) materi pelatihan permen jelly antanan;

3) alokasi waktu pelatihan yang dibutuhkan;

4) metode pelatihan yang akan dilakukan; dan

5) sumber, media dan alat pelatihan yang akan digunakan.

Kedua, ujicoba untuk memperoleh formula yang tepat untuk dilatihkan kepada santri di Pesantren Sabila dan prototype produk yang akan dihasilkan sekaligus sebagai contohcontoh dalam proses pelatihan.

Ketiga, penyusunan media dan hand out untuk mendapatkan :

1) media pembelajaran yang akan digunakan dalam bentuk power point, media nyata (produk), foto, dsb; dan

2) hand out materi pelatihan yang akan diberikan kepada peserta.

Keempat, persiapan pelaksanaan yang untuk :

1) menyiapkan bahan dan alat pelatihan;

2) terkoordinasikan dengan pihak pesantren untuk persiapan tempat, peserta dan hal teknis lain yang dibutuhkan untuk pelatihan;

3) penggandaan hand out; dan

4) persiapan transportasi dan distribusi logistic pelatihan.

Kelima, pelaksanaan pelatihan untuk memastikan bahwa:

1) peserta pelatihan dapat mengetahui dan memahami kandungan dalam tanaman antanan;

2) peserta dapat mengetahui manfaat tanaman antanan terutama untuk meningkatkan daya ingat; dan

3) peserta pelatihan dapat membuat jeli permen antanan.

Keenam, evaluasi pelatihan untuk memperoleh informasi tentang kualitas proses dan hasil pelatihan. Kegiatan dilaksanakan mulai bulan Juli sampai dengan September 2015.

\section{PELAKSANAAN DAN HASIL KEGIATAN}

Pelaksanaan kegiatan pengabdian masyarakat dengan judul : "Pelatihan Pembuatan Permen dan Jelly Antanan Sebagai Suplemen Untuk Meningkatkan Kemampuan Daya Ingat Bagi Santri Penghafal Al-Quran di Pesantren Sabila Citeureup Bogor" dilakukan dalam beberapa tahapan dari mulai persiapan, pelaksanaan sampai evaluasi hasil pelatihan. Setiap tahapan pelaksanaan kegiatan pelatiha diuraikan sebagai berikut.

\section{A. Penyusunan Konsep Pelatihan}

Tahapan pertama yang dilakukan ialah penyusunan konsep pelatihan yang akan dilaksanakan. Hasil tahapan penyusunan konsep pelatihan sebagai berikut:

Pertama, teridentifikasi standar kompetensi, kompetensi dasar dan indikator hasil pelatihan sebagai berikut :

1) standar kompetensi yang mencakup:

(a) memahami pemanfaatan tanaman antanan dalam bentuk permen jelly untuk meningkatka daya ingat, dan

(b) membuat permen jelly antanan berbahan dasar antanan untuk 
meningkatkan kemampuan daya ingat;

2) kompetensi dasar yang mencakup:

(a) memahami klasifikasi antanan;

(b) memahami morfologi antanan,

(c) memahami kandungan aktif pegagan,

(d) memahami efek bilogi dan efek farmakologi pegagan,

(e) memahami komponen pegagan yang berkhasiat dalam peningkatan regenerasi memori,

(f) memahami penggunaan antanan di masyarakat, dan

(g) membuat permen jelly antanan untk meningkatkan daya ingat; dan

3) indikator hasil pelatihan yang terdiri dari :

(a) peserta pelatihan dapat menjelaskan klasifikasi antanan,

(b) peserta pelatihan dapat menjelaskan morfologi antanan,

(c) peserta pelatihan dapat menguraikan kandungan aktif pegagan,

(d) peserta pelatihan dapat menjelaskan efek bilogi dan efek farmakologi pegagan,

(e) peserta pelatihan dapat menjelaskan komponen pegagan yang berkhasiat dalam peningkatan regenerasi memori,

(f) peserta pelatihan dapat menjelaskan penggunaan antanan di masyarakat,

(g) peserta pelatihan dapat memproduksi permen jelly antanan untuk meningkatkan daya ingat,

(h) teridentifikasi materi pelatihan permen jelly antanan.

Kedua, mengidentifikasi materi pelatihan yang dibutuhkan untuk disampaikan kepada peserta pelatihan yaitu :

a) pengenalan tanaman antanan / pegagan yang mencakup klasifikasi antanan, morfologi antanan, kandungan aktif pegagan, efek bilogi dan efek farmakologi pegagan, komponen pegagan yang berkhasiat dalam peningkatan regenerasi memori, dan penggunaan antanan di masyarakat, dan

b) cara membuat membuat permen jelly antanan yang mencakup materi persiapan alat dan bahan, proses produksi, dan pengemasan.

Ketiga, mengidentifikasi alokasi waktu pelatihan yang dibutuhkan. Berdasarkan hasil analisis diketahui alokasi waktu yang dibutuhkan untuk melakukan pelatihan ini selama enam jam pelatihan, di mana setiap jam pelatihan terdiri dari 60 menit. Sehingga total waktu yang dibutuhkan selama 360 menit.

Keempat, mengidentifikasi metode pelatihan yang akan dilakukan. Berdasarkan hasil kajian, metode pelatihan yang tepat digunakan yaitu ceramah, tanya jawab, tutorial, dan praktik membuat permen jelly antanan.

Kelima, mengidentifikasi sumber, media dan alat pelatihan yang akan digunakan. Berdasarkan hasil kajian, sumber belajar yang tepat digunakan ialah naras umber yang ahli di bidang tata boga, yaitu Dra. Nurlaila A. M., M.Kes dan Mulyati, S.Pd., M.Si. Media pembelajaran yang digunakan ialah slide presentasi berupa powerpoint dan produk permen jelly antanan (sampel). Alat pelatihan yang digunakan yaitu laptop, LCD Projector, alat dan bahan pembuatan permen jelly antanan.

\section{B. Uji Coba}

Sebelum dilaksanakan pelatihan, terlebih dahulu perlu dilakukan ujicoba pembuatan permen jelly antanan. Ujicoba dilakukan agar pada saat pelatihan tidak terjadi gagal produksi, serta dapat mengantisipasi segala kemungkinan yang terjadi selama proses pembuatan permen jelly antanan. Ujicoba pembuatan juba bertujuan untuk mendapatkan sampel produk yang akan tunjukkan kepada peserta pelatihan. Selain itu, ujicoba juga digunakan sebagai bagian dari proses pembuatan media 
pembelajaran berupa foto untuk setiap tahapan pembuatan permen jelly antanan. Kegiatan ujicoba dilakukan selama bulan Agustus 2015. Tahapan ujicoba yang dilakukan sebagai berikut :

1) tanaman antanan dicuci sampai bersih sehingga tidak ada kotoran;

2) potong tanaman antanan yang telah dicuci bersih menjadi bagian-bagian kecil. Pemotongan ini dilakukan agar tanaman mudah saat diblender;

3) lakukan penghalusan tanaman antanan dengan cara diblender, pastikan bahwa hasil blender benarbenar halus sehingga saripati dari antanan dapat keluar;

4) masukkan potongan tanaman antanan ke dalam blender, kemudian masukkan air, lalu blender sampai halus;

5) untuk mendapatkan ekstrak, pegagan yang telah dihaluskan kemudian diperas sampai keluar sari-sarinya, untuk ampasnya dibuang;

6) tahapan selanjutnya ialah memasukkan air sebanyak $300 \mathrm{ml}$, dan ekstrak pegagan sebanyak 200 $\mathrm{ml}$ ke dalam panic, kemudian masukkan gula 800 gram dan empat bungkus agar-agar. Masak dengan api sedang sambal diaduk-aduk sampai mendidih;

7) setelah mendidih, masukkan ke dalam cetakan yang telah disediakan, kemudian diamkan selama satu jam, Setelah satu jam, masukkan ke dalam freezer selama 1 jam;

8) potong-poong cetakan permen jelly antanan dengan ukuran $1 \mathrm{~cm} \mathrm{x} 1 \mathrm{~cm}$ $\mathrm{x} 1 \mathrm{~cm}$, kemudian jemur selama tiga hari di bawah terik matahari sampai keluar kristal-kristal gulanya;

9) setelah selesai proses penjemuran, permen jelly antanan telah jadi dan siap untu dikems sesuai dengan kemasan yang diinginkan, bisa dalam bentuk kemasan plastic, toples atau jar;

10) Setelah permen jelly antanan jadi,

tahapan selanjutnya ialah perancangan dan pembuatan kemasan permen jelly antanan. Untuk pembuatan langkah-langkah yang telah dilaksanakan diuraikan sebagai berikut.

Pertama, proses desain label kemasan plastik. Untuk penjualan produk permen jelly antanan diperlukan kemasan yang menarik bagi konsumen. Maka dari ditu dibuat desain dengan bentuk dan kombinasi warna yang menarik bagi anak usia sekolah.

Kedua, proses desain label kemasan jar. Kemasan jar juga dibuat sebagai variasi bentuk kemasan yang dapat digunakan oleh para santri. Gunakan desain label kemasan yang telah dicetak pada permen jelly antanan kemasan plastik dan jar.

\section{Penyusunan Media dan Hand Out}

Untuk mendukung efektivitas kegiatan pelatihan pembuatan permen jelly antanan, diperlukan media pembelajaran dan hand out yang akan dibagikan kepada peserta pelatihan. Media pembelajaran yang digunakan berupa slide power point, foto, produk permen jelly antanan, hand out untuk peserta pelatihan. Penyusunan media pembelajaran dan hand out dilakukan pada bulan Agustus 2015. Media pembelajaran dalam bentuk slide powerpoint terlampir.

\section{Persiapan Pelaksanaan}

Agar kegiatan pelatihan berjalan dengan lancar, terlebih dahulu perlu dilakukan persiapan yang baik. Kegiatan persiapan dilakukan pada bulan Agustus dan awal September sebelum tanggal 11. Hal-hal yang dipersiapkan antara lain: (1) bahan dan alat pelatihan; (2) koordinasi dengan pihak pesantren untuk persiapan tempat, peserta dan hal teknis lain yang dibutuhkan untuk pelatihan; (3) penggandaan hand out materi pelatihan; (4) persiapan transportasi, dan (5) distribusi logistik pelatihan.

\section{E. Pelaksanaan Pelatihan}


Pelaksanaan kegiatan pelatihan dilakukan pada tanggal 11 September 2015 bertempat di Aula Prondok Pesantren Sabilia Citeureup Kabupaten Bogor. Pelatihan dimulai pada pukul 08.00 sampai dengan pukul 16.00 WIB. Acara pelatihan dimulai dengan sambutan pimpinan Ponpes Sabilia, sambutan ketua tim pengabdian masyarakat (Tarma, S.Pd., M.Pd) dan dilanjutkan dengan materi (teori) serta praktik pembuatan permen jelly antanan. Pelaksanaan kegiatan dihadiri oleh pimpinan dan pengasuh Ponpes Sabilia, 3 orang dosen pelaksana kegiatan, 20 orang santri sebagai peserta pelatihan. Kegiatan pelatihan berjalan lancer dan mencapai tujuan yang diharapkan.

\section{F. Evaluasi Pelatihan}

Untuk mengetahui dan meastikan bahwa kegiatan telah mencapai tujuan yang diharapkan maka diperlukan adanya evaluasi. Evaluasi dilakulan berdasarkan kinerja yang ditunjukkan oleh peserta pelatihan serta pandangan peserta pelatihan tentang proses pelatihan yang telah dilaksanakan. Secara umum diketahui bahwa peserta pelatihan telah menguasai materi pelatihan.

Berdasarkan pelaksanaan "Pelatihan Pembuatan Permen dan Jelly Antanan Sebagai Suplemen Untuk Meningkatkan Kemampuan Daya Ingat Bagi Santri Penghafal Al-Quran di Pesantren Sabila Citeureup Bogor” yang telah dilaksanakan pada tanggal 11 September 2015, diperoleh hasil sebagai berikut:

(1) peserta pelatihan dapat menjelaskan klasifikasi antanan;

(2) Peserta pelatihan dapat menjelaskan morfologi antanan;

(3) Peserta pelatihan dapat menguraikan kandungan aktif pegagan;

(4) Peserta pelatihan dapat menjelaskan efek bilogi dan efek farmakologi pegagan;

(5) Peserta pelatihan dapat menjelaskan komponen pegagan yang berkhasiat dalam peningkatan regenerasi memori;

(6) Peserta pelatihan dapat menjelaskan penggunaan antanan di masyarakat;

(7) Peserta pelatihan dapat memproduksi permen jelly antanan untuk meningkatkan daya ingat.

\section{KESIMPULAN DAN REKOMENDASI}

Setelah selesainya kegiatan pengabdian masyarakat berupa pelatihan pembuatan permen jelly antanan sebagai supplement untuk meningkatkan daya ingat bagi satri penghafal Al Quran di Pesantren Sabilia Citeureup Kabupaten Bogor, ada beberapa hal yang dapat disimpulkan, yaitu:

1. Kegiatan berjalan efektif dan efisien sesuai dengan rencana yang telah ditetapkan sebelumnya.

2. Setiap tahapan kegiatan dari mulai persiapan, pelaksanaan dan evaluasi berjalan sesuai rencana yang telah ditetapkan.

3. Peserta pelatihan dapat menguasai sepenuhnya materi pelatihan yang telah diajarkan dan dilatihkan.

4. Pimpinan Ponpes Sabilia menanggapi positif pelaksanaan kegiatan pelatihan ini dan mengharapkan kegiatan pelatihan selanjutnya.

Berdasarkan proses yang dijalani selama kegiatan pengabdian masyarakat ini, ada beberapa hal yang perlu direkomendasikan, yaitu :

1. Bagi Pesantren Sabilia, diharapkan dapat mendayagunakan dan memanfaatkan pengetahuan dan keterampilan para santri dalam membuat permen jelly antanan setelah kegiatan pelatihan selesai. Serta dapat melakukan proses produksi baik untuk memenuhi kebutuhan para santri sendiri atau untuk dijual ke masyarakat luas.

2. Bagi LPM, diharapkan kegiatan pengabdian masyarakat terus dilaksanakan pada tahuntahun selanjutnya dengan biaya yang lebih besar agar lebih banyak manfaat yang dapat diberikan kepada masyarakat 